\title{
Epidemiology of vaginal candidiasis among pregnant women attending Tikrit teaching hospital/Iraq.
}

\author{
Ehan A. Alsharifi*
}

MBChB, PhD

JFac Med Baghdad 2017; Vol.59, No .4 Receive Dec. 2017 Accepted Jan .2018

Back ground: Vaginal candidiasis is the second common infection among child bearing women. The disease is caused by yeast organism especially Candida albican. Pregnancy is one of the risk factors of the disease. It has been revealed that more than $75 \%$ of women may experience an attach of the disease during their life time.

Objectives: To study the epidemiological factors of vaginal candidiasis among pregnant women attending Tikrit teaching hospital out-patient clinic.

Patients and methods: The study was conducted on a sample of (120) pregnant women. The demographic and epidemiologic information was obtained according to special designed questionnaire. The study was done over a period from 1/3/2017 to $16 / 4 / 2017$. Vaginal swabs were taken from patients and sent to the lab for direct microscopically examination and cultured in special nutrient media.

Results: About (29\%) of study sample had vaginal candidiasis. There was a significant relation between a history of taking antibiotic, oral contraceptive drugs, diabetes mellitus and occurrence of the disease. The most frequent cases of vaginal candidiasis was from age group (25-35 years) $(57.1 \%)$.

Conclusions: About (29\%) of pregnant women sample was affected by vaginal candidiasis. There was a significant relation between history of using oral contraceptive pills, broad spectrum antibiotics taking, diabetes mellitus and occurrence of the disease.

Key words: pregnant women, epidemiology, vaginal candidiasis.

\section{Introduction:}

Vaginal candidiasis is a yeast infection of vagina. Candida is one of the normal flora of genital tract. As a result of disturbance in the genital environment as a result certain factors proliferation of yeast (Candida) leading to vaginal candidiasis. It has been documented that about $75 \%$ of women may be affected by the disease at least once at life time. About more than $90 \%$ of vaginal candidiasis was caused by Candida albican (1, 2, and 3). The most important risk factors of vaginal candidiasis are pregnancy, oral contraceptive drugs, broad spectrum antibiotics (3, 4, 5, and 6) and uncontrolled diabetes mellitus (7). It has been reported that the frequency of vaginal candidiasis among pregnant women was different according to many studies. In Libya the result was (43.8\%) (2), in Kenya $42.7 \%$ (8), in Nigeria (62.2\%) (9) and in Saudia Arabia ( $24 \%$ ) (10). The common signs and symptoms of the vaginal candidiasis are itching, white cheesy discharge, and dysuria, dyspareunia $(3,11,12$, and 13). Vaginal candidiasis is more frequent among age group 25-35 years. This was reported in Saudia arabia about $(56 \%)(10)$, in Kenya $(60 \%)(8)$, in Benin (55\%)(14).

*Dept. Of Microbiology, University of IbnSena for Medical Sciences, Email: Abidahmad60@yahoo.com.
Patients and methods:

It was descriptive study conducted on pregnant women attending Tikrit Teaching Hospital over a period from 1/3-16/4/2017. The sample included 120 pregnant mothers. Demographic information was obtained according to special designed questionnaire. All pregnant mothers was examined clinically by specialist and vaginal swabs were taken from those clinically diagnosed as affected by vaginal candidiasis. The vaginal swabs were sent to lab for direct microscopically examination by using $\mathrm{KOH}$ solution and cultured in Sabouraud dextrose agar (SDA) and incubated under 37 ć for 72 hours $(3,7,15,16)$.

\section{Results:}

Table (1) Distribution of Pregnant Vaginal Candidiasis cases According to age group .

\begin{tabular}{llllll}
\hline $\begin{array}{l}\text { Age } \\
\text { years }\end{array}$ & in & Diseased & $\begin{array}{l}\text { Not } \\
\text { diseased }\end{array}$ & Total \\
\hline$<25$ & 5 & $14.3 \%$ & 15 & 20 & $16.6 \%$ \\
\hline $25-35$ & 20 & $57.1 \%$ & 47 & 67 & $55.8 \%$ \\
\hline $36-45$ & 8 & $22.9 \%$ & 20 & 28 & $23.4 \%$ \\
\hline$>45$ & 2 & $5.7 \%$ & 3 & 5 & $4.2 \%$ \\
\hline Total & 35 & 85 & 120 & $100 \%$ \\
& 29.16 & 70.84 & & $100 \%$
\end{tabular}

The frequency of vaginal candidiasis among all pregnant women sample was $(29.16 \%)$. It has been revealed that the highest frequency of pregnant vaginal candidiasis among age group (25-35)years 
(57.1\%) followed by age group (36-45) years $(22.9 \%)$ and the lowest among age more than 45 years $(5.7 \%)$.Table(1).

Table (2) Distribution of Pregnant Vaginal Candidiasis cases According to history of antibiotic taking.

\begin{tabular}{llll}
\hline $\begin{array}{l}\text { Antibiotic } \\
\text { taking }\end{array}$ & Diseased & Not diseased & Total \\
\hline yes & 29 & 49 & 78 \\
& $37.2 \%$ & $62.8 \%$ & $100 \%$ \\
\hline No & 6 & 36 & 42 \\
& $14.3 \%$ & $85.7 \%$ & $100 \%$ \\
\hline Total & 35 & 85 & 120
\end{tabular}

The chi-square statistic is 6.5006 . The $p$-value is .010784 . This result is significant at $p<.05$.

Regarding a history of receiving antibiotics, it has been found that there is a significant relation between taking antibiotics and occurrence of the disease. The frequency of affected pregnant women with a history of taking antibiotics $(37.2 \%)$ while only $(14.3 \%)$ of those who had not taking antibiotics. Table (2)

Table (3) Distribution of Pregnant Vaginal cases According to history of oral contraceptive drug using

\begin{tabular}{llll}
\hline $\begin{array}{l}\text { Oral } \\
\text { contraceptive }\end{array}$ & Diseased & Not diseased & Total \\
\hline User & 24 & 37 & 61 \\
& $39.3 \%$ & $60.7 \%$ & $100 \%$ \\
\hline Not user & 11 & 48 & 59 \\
& $18.6 \%$ & $81.4 \%$ & $100 \%$ \\
\hline Total & 35 & 85 & 120
\end{tabular}

The chi-square statistic is 6.2205 . The $p$-value is .012628 . This result is significant at $p<.05$.

Table (3) shows that (39.3\%) of pregnant women who were with history of using oral contraceptive drugs had vaginal candidiasis while only $(18.6 \%)$ of non oral contraceptive drug users was affected by the disease. It is a significant relation between oral contraceptive drug users and non users.

Table (4) Distribution of Pregnant Vaginal Candidiasis According to presence of diabetes mellitus.

\begin{tabular}{llll}
\hline $\begin{array}{l}\text { Diabetic } \\
\text { disease }\end{array}$ & $\begin{array}{l}\text { Vaginal } \\
\text { candidiasis }\end{array}$ & $\begin{array}{l}\text { No vag. } \\
\text { candidiasis } \\
\text { diseased }\end{array}$ & Total \\
\hline Diabetic & 11 & 12 & 23 \\
& $47.8 \%$ & $52.2 \%$ & $19.2 \%$ \\
& & 73 & $100 \%$ \\
\hline Not diabetic & 24 & $75.3 \%$ & $80.8 \%$ \\
& $24.7 \%$ & 85 & $100 \%$ \\
\hline Total & 35 & & $100 \%$
\end{tabular}

The chi-square statistic is 4.7952 . The $p$-value is .028539 . This result is significant at $p<.05$.

Table (4) shows that $(47.8 \%)$ of diabetic and $(24.7 \%)$ of non-diabetic pregnant mother had vaginal candidiasis and there is a significant relation between diabetes mellitus disease and occurrence of vaginal candidiasis.

Fig (1) Distribution of Pregnant Vaginal Candidiasis According to trimester.

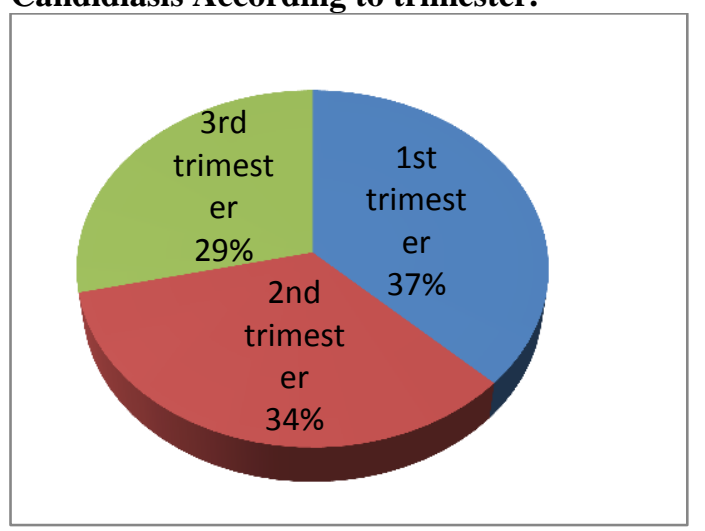

The highest frequency of vaginal candidiasis was among those in $1^{\text {st }}$ trimester of pregnancy $(37 \%)$ followed by those in $2^{\text {nd }}$ trimester $(34 \%)$ and the lowest among those in $3^{\text {rd }}$ trimester $(29 \%)$. Fig (1).

\section{Discussions:}

Candidiasis is the second disease of vaginitis in women. Pregnancy is one of the risk factors of vaginal candidiasis (3). In the current study it has been found that about $29 \%$ of pregnant women with vaginal candidiasis. The result is less than that reported in Nigeria $(62.2 \%)(9)$, Tanzania (42.9\%) (17), Libya (43.8\%) (2) and more than reported in Saudia Arabia (24\%) (10), Nigeria (26\%) (18). This high frequency was attributed to suppression in the immunity of body as a result of pregnancy which lead to disturbance in the balance between yeast and lactobacillus bacteria and the end result proliferation of yeast leading to occurrence of the disease $(6,15)$. It has been reported in the current study that the highest frequency of vaginal candidiasis cases were among age group $25-35$ years $(57.1 \%)$. This result is lower to that reported by Nelson et al in Kenya $(60 \%)(8)$ and nearly similar to that reported in Saudia Arabia(56\%) (10) and in Nigeria (57\%) (19). This result is higher than reported in Benin city $(55 \%)$ (14). The more frequent cases among this age group was attributed that there is more sexual activity, more using antibiotic, more using of oral contraceptive pills in addition to pregnancy as a risk factor $(4,5,18)$. The current study shows that about (37\%) of pregnant mother with history of taking antibiotics and about (14\%) of those with negative history was affected by the disease. There is a significant relation between taking antibiotics and occurrence of the disease as reported by other studies (20). This results is lower than that reported in Kenya (70\%) (8). It has been reported in Saudia Arabia that there is no significant relation even the frequency was (18.6\%) (10). Taking antibiotics affect on Lactobacillus bacteria in the vagina leading to proliferation of yeast and occurrence of the 
disease $(21,22$, and 23$)$. It has been revealed that about $(39 \%)$ of pregnant mother who had history of using oral contraceptive pills and about $(18 \%)$ of non-users were affected by the disease. It has been reported in Kenya that (80\%) of oral contraceptive pills users affected by the disease (8). The current result shows a significant relation between using oral contraceptive pills and occurrence of vaginal candidiasis as reported in other studies $(20,24$, and 25). In Saudia Arabia a study conducted by Al-akeel et al, they found there is no significant relation even the frequency was more than $(27 \%)$ among oral contraceptive pills users (10). The frequency of vaginal candidiasis cases among pregnant women with diabetes mellitus disease was more than $(47.8 \%)$ while it was about $(24.7 \%)$ among nondiabetics. There is a significant relation between diabetes mellitus and occurrence of vaginal candidiasis. The highest frequency of vaginal candidiasis among diabetic than non-diabetic was reported by other studies which attribute to increase glucose level in genital tissues $(7,26)$. Regarding the distribution of cases according to trimester, the more frequent cases were reported among those with $1^{\text {st }}$ trimester $(37 \%)$ followed by $2^{\text {nd }}$ trimester $(34 \%)$ and the lowest were among those in $3^{\text {rd }}$ trimester $(29 \%)$. In contrast the results of other studies they found highest frequency among those with $3^{\text {rd }}$ trimester about $(68 \%), 2^{\text {nd }}$ trimester about $(21 \%)$ and $1^{\text {st }}$ trimester about $(11 \%)(8,27)$. This difference may be that in the current study the lowest frequency among $3^{\text {rd }}$ as a result of receiving treatment after diagnosis in $1^{\text {st }}$ trimester.

\section{Conclusions:}

In addition to pregnancy as a risk factors to vaginal candidiasis, it has been documented that history of taking antibiotics, oral contraceptive pills and diabetes mellitus were playing as a significant risk factors.

\section{References:}

1. Saporiti AM, Gómez D, Levalle S, Galeano M, Davel $\quad G$, Vivot $\quad W_{-}$, Rodero $\quad$ L.Vaginal candidiasis: etiology and sensitivity profile to antifungal agents in clinical use. Revista Argentina Microbiologia .2001,33(4):217-222.

2. Altayyar I A, Alsanosi A $S$ \& Osman $N$ A(2016).Prevalence of vaginal candidiasis among pregnant women attending different gynecological clinic at South Libya .European Journal of Experimental Biology. 2016;6(3):25-29

3.Stoppler MC. Yeast infection (In Women \& Men). 2017; Available on :

http://www.medicinenet.com/yeast infection in wo men and men/page2.htm

4. Fidel Jr PL, Barousse M, Espinosa T, Ficarra M, Sturtevant J, Martin DH, Quayle AJ, Dunlap K. An intravaginal live Candida challenge in humans leads to new hypotheses for the immunopathogenesis of vulvovaginal Candidiasis. Infect. Immun.2003; 72(5):2939-2946.available

in http://dx.doi.org/10.1016/S0002-9378(12)90722-X

5. Jindal N, Gill P, Aggarwal A. Significance of Candida culture in women with vulvovaginal symptoms. J. Obstet. Gynecol. India.2006; 56:139141.

6. CDC, Centers for Disease Control and Prevention. Sexually Transmitted Diseases Treatment Guidelines. 2010; 59(RR12):1-110.

7. Faraji R, Rahimi MA, Rezanmadani F, Hashemi M.Prevalence of vaginal candidiasis infection in diabetic women. Afr. J. Microbiol. Res. 2012; 6(11):2773-2778.

8. Nelson $M$, Wangiru $W$, Margaret $M W$. Prevalence of Vaginal Candidiasis and Determination of the Occurrence of Candida Species in Pregnant Women Attending the Antenatal Clinic of Thika District Hospital, Kenya. Open Journal of Medical Microbiology. 2013;3,264272 available

on (http://www.scirp.org/journal/ojmm)

9. Akahl $P$ A, Nnamani $C E$, and Nnamani $P O$. Prevalence and treatment outcome of vulvovaginal candidiasis in pregnancy in a rural community in Enugu State, Nigeria. Journal of Medicine and Medical Sciences .2010; Vol. 1(10) pp. 447452Available online http://www.interesjournals.org/JMMS.

10. Al-akeel R A, El-Kersh T A, Al-Sheik Y A, \& AlAhmady $Z$ Z. Prevalence and comparison for detection methods of Candida species in vaginal specimens from pregnant and non pregnant Saudi women . African Journal of Microbiology Research. 2013 Vol. 7(1), pp. 56-65. Available online at http://www.academicjournals.org/AJMR 11. Hedayati, T. and G. Shafiei. Candidiasis. 2010. eMedicine Specialties.

12. Hoefgen HR, Merritt DF. Vulvovaginitis. In: Kliegman RM, Stanton BF, St Geme JW, Schor NF, eds. Nelson Textbook of Pediatrics. 20th ed. Philadelphia, PA: Elsevier; 2016: chap 549.

13. Kauffman CA. Candidiasis. In: Goldman L, Schafer AI, eds. Goldman's Cecil Medicine. 25th ed. Philadelphia, PA: Elsevier Saunders;chap ,2016;338.

14. Okungbowa FI, Isikhuemhen OS, Dede AP. The distribution frequency of Candida species in the genitourinary tract among symptomatic individuals in Nigerian cities. Rev. Iberoam. Micol.2003; 20(2):60-63.

15. Corsello, S, Spinillo, A, Osnengo, G et al. An epidemiological survey of vulvovaginal candidiasis in Italy. Eur $J$ Obstet Gynecol Reprod Biol. 2003;110: 66-72

16. Nyirjesy $P$. Vulvovaginal Candidiasis and bacterial vaginosis. Infect. Dis. Clin. 2008; 22(4):637-665.

17. Feyi $P$ and Amadi $A$. "The Prevalence and Pattern of Vaginal Candidiasis in Pregnancy in Abia," Journal of Medical Investigation and Practice. 2001; Vol. 2, pp. 25- 27. 
18. Donbraye-Emmanuel $O O B$, Donbraye $E$, Okonko I O, Ali J A, Ojezele $M O \&$ Nwanze $J C$. Detection and prevalence of Candida among pregnant women in Ibadan, Nigeria. World Applied Sciences Journal: 2010; 10 (9): 986-991

19. Akortha E,Chikwe $O$ and Nwaugo O. "Antifungal Re- sistance among Candida Species from Patients with Ge- nitourinary Tract Infection Isolated in Benin City, Edo estate, Nigeria," African Journal of Microbiology Re-search. 2009; Vol. 3, No. 11, pp. 694-699

20 .Xu J, Schwartz K, Bartoces M, Monsur J, Richard BS, Severson K, Sobel JD. Effect of antibiotics on vulvovaginal Candidiasis: a Metro Net Study. J. Am. Board. Fam. Med. 2008;21(4):261-268.

21. Хu J, Sobel JD. Antibiotic-associated vulvovaginal candidiasis. Current Infectious Disease Reports. 2003;5(6):481-487.

22. Eckert LO . Acute vulvovaginitis. The New England Journal of Medicine. 2006; 355(12):12441252.
23 .Achkar JM, Fries BC. Candida infections of the genitourinary tract. Clinical Microbiology Reviews;2010; 23(2):253-273.

24. Yusuf A, Chowdhury AQ, Rahman ANS M. Evaluation of the effect of contraceptives on prevalence of Candida species on vaginal Candidiasis in Dhaka, Bangladesh. Bangladesh J. Med. Microbiol.2007; 1(2):61-64.

25. Bahram A, Hamid B, Zohre T. Prevalence of Bacterial Vaginosis and Impact of Genital Hygiene Practices in Non-Pregnant Women in Zanjan, Iran. Oman Med. J. 2009;24:288-293.

26. Barousse MM, Van Der Pol BJ, Fortenberry D, Orr D, Fidel Jr PL . Vaginal yeast colonisation, prevalence of vaginitis, and associated local immunity in adolescents. Sex Transm. Infect.2004; 80:48- 53.

27. Sobel J. "Epidemiology and Pathogenesis of Recurrent Vulvovaginal Candidiasis. American Journal of Obstet- rics and Gynecology, 2000; Vol. 152, $\quad$ pp. 924-935. 